\title{
ROZPOWSZECHNIANIE UTWORÓW A AUTORSKIE PRAWA MAJĄTKOWE JAKO PRZEDMIOT HARMONIZACJI W PRAWIE UNII EUROPEJSKIEJ
}

Celem niniejszego artykułu jest syntetyczne spojrzenie na zmiany, jakie zachodziły w zakresie prawa do rozpowszechniania utworów od momentu uchwalenia ustawy o prawie autorskm i prawach pokrewnych ${ }^{1} \mathrm{z}$ uwzględnieniem kolejnych nowelizacji, a także dorobku orzecznictwa. Rozważania zawężono do istotnego aktualnie problemu, jakim jest uznanie przez Trybunał Sprawiedliwości Unii Europejskiej (TS, Trybunał), że harmonizacja w zakresie prawa do publicznego udostępniania utworu ma charakter maksymalny. Konsekwencją takiej wykładni jest ograniczenie swobody do wprowadzania w prawie krajowym rozwiązań odmiennych od standardu unijnego, a w szczególności przyznawania twórcom dalej idącej ochrony, niż wynika to z prawa Unii Europejskiej.

Głównym przedmiotem dalszej analizy są art. 6 ust. 1 pkt 3 pr.aut. (zawierający definicję utworu rozpowszechnionego), art. 50 pkt 3 pr.aut. oraz art. 24 ust. 2 pr.aut. Warto zauważyć, że właśnie te postanowienia uzyskały aktualny kształt w 2004 r., w roku akcesji Polski do Unii Europejskiej. Zmiany, jakie zaszły $\mathrm{w}$ redakcji powyższych postanowien, związane sa, choćby pośrednio, ze wdrożeniem przede wszystkim dyrektywy 2001/29/WE o prawie autorskim i prawach pokrewnych $\mathrm{w}$ społeczeństwie informacyjnym ${ }^{2}$. W chwili obecnej nie ma konkretnych propozycji legislacyjnych zmian lub wprowadzenia nowych postanowień dotyczących autorskich praw majątkowych $\mathrm{w}$ zakresie rozpowszechniania. Aktywna rolę pełni natomiast TS, którego orzecznictwo od 2013 r. zaczęło dotyczyć również nowych, pod względem technologicznym, sposobów korzystania z utworów. Ciekawe wydaje się zagadnienie, czy wykładnia polskiego prawa pozwoli na osiagnięcie rezultatów założonych w dyrektywie 2001/29/WE, w taki sposób jak rozumie to interpretujący ją Trybunał. W niniejszym artykule poruszone zostaną kwestie zakresu harmonizacji na przykładzie dwóch problemów widocznych na tle orzecznictwa: udostęp-

1 Ustawa o prawie autorskim i prawach pokrewnych z 4 lutego 1994 r., t.jedn.: Dz. U. 1994, Nr 24, poz. 83 ze zm (dalej jako: pr.aut.).

2 Dyrektywa PEi Rady 2001/29/WE z 22 maja 2001 r. w sprawie harmonizacji niektórych aspektów praw autorskich i pokrewnych w społeczeństwie informacyjnym, Dz. Urz. L 167 z 22 czerwca 2001 r., Polskie wydanie specjalne: Rozdział 17, Tom 001, s. 230-239. 
niania publicznego, które nie łączy się z osiaganiem korzyści majątkowych, oraz zamieszczania odesłań internetowych (linków) do rozpowszechnionych utworów.

\section{POSTANOWIENIA DOTYCZACEE ROZPOWSZECHNIANIA UTWORÓW W POLSKIEJ USTAWIE}

W art. 6 zawarto definicje pól eksploatacji, o których mowa w art. 50 pr.aut. W związku z obowiązkiem przyznania autorom w prawie krajowym prawa do tzw. udostępniania na żądanie, a więc uprawnienia związanego z eksploatacja internetową utworów, nowelizacją z $2002 \mathrm{r}^{3}$. uporządkowano i skategoryzowano pola eksploatacji. Zamiast wyliczenia różnych pól eksploatacji wprowadzono trzy główne kategorie, odpowiadające trzem głównym uprawnieniom będącym przedmiotem harmonizacji w dyrektywie 2001/29/WE. Wskazano na pola eksploatacji w zakresie zwielokrotniania, obrotu egzemplarzami utworu i w zakresie rozpowszechniania. Wyliczenie zawarte w art. 50 pkt 3 pr.aut. nie ma charakteru wyczerpującego, a zgodnie z konstrukcja praw autorskich i art. 17 pr.aut. - prawo autorskie może objąć również inne formy korzystania, jeśli będą stanowić „rozpowszechnienie utworu”. W ramach „,rozpowszechniania" wymieniono takie pola eksploatacji, jak: publiczne wykonanie, wystawienie, wyświetlenie, odtworzenie oraz nadawanie i reemitowanie, a także publiczne udostępnianie utworu w taki sposób, aby każdy mógł mieć dostęp w miejscu i czasie przez siebie wybranym. W zakresie uprawnień wiążących się z transmisja, wprowadzono do katalogu pól eksploatacji pojęcie „reemisji” i wskazano na samo „nadanie”, bez odrębnego wskazania na różne technologiczne sposoby przekazu. W zakresie prawa do udostępniania na żądanie tekst polskiej ustawy jest w zasadzie identyczny z tekstem dyrektywy 2001/29/WE, w której w art. 3 ust. 1 zobowiazzano państwa członkowskie do przyznania autorom szerokiego prawa do publicznego udostępniania utworów, włączając „podawanie do publicznej wiadomości ich utworów w taki sposób, że osoby postronne maja do nich dostęp w wybranym przez siebie miejscu i czasie". Pojęcie „podawania do publicznej wiadomości” zastapiono w polskiej ustawie pojęciem „udostępniania”, co jest spójne z definicją rozpowszechniania wynikająca z art. 6 ust. 1 pkt 3 pr.aut. Nowelizacją z 1 kwietnia 2004 r. wprowadzono zmianę w aktualnym art. 6 ust. 1 pkt 3, dodając, że rozpowszechnieniem jest udostępnienie w ,jakikolwiek sposób”4. Podkreślenie, że chodzi o „jakikolwiek sposób”, może się wiązać z poszerzeniem katalogu pól eksploatacji w art. 50 pkt 3 pr.aut., ale też z treścią dyrektywy i zobowiązaniem państw członkowskich do objęcia monopolem autorskim „jakiegokolwiek” publicznego udostępniania utworów. Jednocześnie trzeba odnotować, że zakresem harmo-

${ }^{3}$ Ustawa z 28 października 2002 r. o zmianie ustawy o prawie autorskim i prawach pokrewnych, Dz. U. 2002, Nr 197, poz. 1662.

${ }^{4}$ Ustawa z 1 kwietnia $2004 \mathrm{r}$ o zmianie ustawy o prawie autorskim i prawach pokrewnych, Dz. U. 2004, Nr 91, poz. 869. 
nizacji w dyrektywie 2001/29/WE objęto jedynie takie formy eksploatacji, przy których występuje „element odległości” pomiędzy nadawcą a publicznością 5 .

Bez wątpienia pod wpływem regulacji unijnych wyraźnie poszerzono zakres prawa do rozpowszechniania utworów, zgodnie z międzynarodową tendencją i potrzebami podmiotów uprawnionych. Nabiera to szczególnego znaczenia w kontekście eksploatacji internetowej. Jednakże nie wszystkie problemy poruszane w orzecznictwie zarówno polskim, jak i TS dotycza eksploatacji w obrocie elektronicznym. Istotna część rozważań w orzecznictwie TS poświęcona jest określeniu zakresu „publicznego” charakteru udostępnienia. W polskiej ustawie zagadnienie zakresu prawa do rozpowszechniania w szczególnym wypadku, jakim są programy radiowe i telewizyjne, wiąże się z wykładnią art. 24 ust. 2 pr.aut. Przepis ten, wprowadzając dozwolony użytek w zakresie publicznego odtwarzania nadań, jeśli nie łączy się z tym osiąganie korzyści majątkowych, może być uznany za próbę wyważania interesów podmiotów uprawnionych, użytkowników odbiorników telewizyjnych i radiowych, oraz innych osób, które w miejscach publicznych mają dostęp do nadań. Warto odnotować, że rozwiązanie to było nowością w ustawie z 1994 r., w stosunku do poprzednich ustaw o prawie autorskim. Monika Czajkowska-Dąbrowska zwraca uwagę, że odbiór programów radiowych, także w miejscu publicznym, był wcześniej wyłączony ze sfery autorskich praw majątkowych ${ }^{6}$. Artykuł 24 ust. 2 pr.aut. podlegał niewielkim zmianom, w nowelizacji z 28 października 2002 r. zmieniono odtwarzanie dźwięków lub dźwięków i obrazów na „programy radiowe lub telewizyjne”, co zawęża zakres zastosowania tego przepisu. O ile więc w kontekście prawa do rozpowszechniania można odnotować rozszerzanie w sensie włączania nowych pól eksploatacji, co podyktowane jest postępem technologicznym, o tyle wprowadzenie i zmiana art. 24 ust. 2 pr.aut. świadczy o zawężaniu sfery dozwolonego użytku w tym zakresie. Kwestia zgodności art. 24 ust. 2 pr.aut. z postanowieniami dyrektywy 2001/29/WE zostanie rozwinięta w dalszej części artykułu. Formalnie natomiast, jeśli chodzi o zgodność polskiej ustawy z art. 3 ust. 1 dyrektywy 2001/29/WE, można stwierdzić, że w momencie akcesji poziom ochrony w prawie polskim był dostosowany do wymogów prawa Unii Europejskiej.

\section{WYKŁADNIA PRAWA DO PUBLICZNEGO UDOSTĘPNIANIA UTWORÓW W ART. 3 UST. 1 DYREKTYWY 2001/29/WE}

Wykładnia Trybunału dopiero od 2013 r. dotyczy sposobów eksploatacji w zakresie nowych technologii i nowych sposobów przekazu internetowego. Wcześniej TS odpowiadał na pytania prejudycjalne związane ze sporami dotyczącymi korzystania z utworów w hotelach lub innych miejscach dostępnych dla ogółu i dokonał wykładni, co znaczy, że przekaz ma charakter publiczny.

${ }^{5}$ Wynika to z motywu 24 preambuły dyrektywy 2001/29/WE.

${ }^{6}$ M. Czajkowska-Dabrowska, Glosa do wyroku SN z 18.11.2004 r. V CK 243/04, OSP 2005, nr 11 , poz. 129 , s. 586 . 
Problem, czy umieszczanie odbiorników w pokojach hotelowych stanowi wkroczenie w majątkowe prawa autorskie w zakresie rozpowszechniania, był równolegle rozpatrywany również w polskim orzecznictwie. Jak wskazuje Elżbieta Traple, w zagranicznym orzecznictwie i doktrynie dopuszczono możliwość tzw. przestrzennej kumulacji publiczności ${ }^{7}$. Bardzo istotne znaczenie dla rozstrzygnięć w sporach przed sądami państw członkowskich miał wyrok TS w sprawie $S G A E^{8}$. W wyroku tym TS wskazał, że przekaz publiczny oznacza przekaz do nieoznaczonego i dość dużego kręgu odbiorców, a klienci hotelu stanowią taka, zmienną w czasie, publiczność. Jak się słusznie wskazuje, uznanie, że dane pojęcie, w tym przypadku cechy „publiczności” przekazu, jest pojęciem autonomicznym, ma istotne znaczenie z punktu widzenia harmonizacji $^{9}$. Można ocenić, że jest to drugi krok w kierunku ujednolicania prawa autorskiego państw członkowskich. Pierwszym krokiem jest przyjęcie przepisów harmonizujących. Ze względu na obowiązek transpozycji przepisów dyrektywy i ukształtowaną w państwach członkowskich tradycję prawna, sformułowaniom dyrektywy można jednak nadawać w prawie krajowym odmienny sens. Początkowo np. uważano, że pojęcie „publiczny” jest pojęciem, którego wykładni należy dokonywać w prawie krajowym ${ }^{10}$. Wyrok w sprawie $S G A E$ powinien wpłynąć na jednolitą wykładnię zakresu prawa do publicznego udostępniania utworów w państwach członkowskich, jednocześnie mógł być przyczyną zakwestionowania niektórych istniejacych rozwiąań krajowych. Kwestię tę dobrze ilustruje wyrok w sprawie $O S A^{11}$.

W ramach sporu pomiędzy organizacją zbiorowego zarządzania a czeskim uzdrowiskiem (obiektem SPA) zakwestionowano przepis czeskiego prawa autorskiego wprowadzający odstępstwo od zapłaty wynagrodzenia z tytułu korzystania z praw autorskich dla zakładów opieki zdrowotnej w ramach świadczonych przez nie usług medycznych. Trybunał, biorac pod uwage zarobkowy charakter działalności uzdrowiska (wskazał, że zakład uzdrowiskowy działa jak przedsiębiorstwo handlowe), podkreślił, że udostępnianie chronionych utworów przez taki podmiot stanowi publiczne udostępnianie i przepisy krajowe nie mogą wprowadzać odstępstw innych niż przewidziane dopuszczalnymi w świetle dyrektywy ograniczeniami i wyjątkami od praw autorskich ${ }^{12}$. Trybunał wskazał też na analogie pomiędzy hotelem a zakładem uzdrowiskowym,

${ }^{7}$ E. Traple, Prawo komunikowania dzieła publiczności bezpośrednio i za pomoca różnych środków technicznych, w: System prawa prywatnego, t. 13: Prawo autorskie, red. J. Barta, Warszawa 2013 , s. 212.

${ }^{8}$ Wyrok TS z 7 grudnia 2006 r. w sprawie C-306/05, Sociedad General de Autores y Editores de España (SGAE) przeciwko Rafael Hoteles SA, Zb. Orz. 2006, I-11519.

${ }^{9}$ Zob. E. Traple, op. cit., s. 213, przyp. 173; jak również referat eadem, Czy parodia, pastisz, karykatura oraz cytat wymagaja nowego podejścia w świetle Dyrektywy Infosoc?, na konferencji „20 lat ustawy o prawie autorskim i prawach pokrewnych”, Poznań, 20 listopada 2014 r.

${ }^{10}$ Commission Staff Working Paper SEC (2004), 995; L. Guibault et al., The Recasting of Copyright and Related Rights for the Knowledge Economy, University of Amsterdam, Amsterdam 2007, s. 57; J. Reinbothe, S. von Lewinski, The EC Directive on Rental and Lending Rights and on Piracy, London 1993, s. 94.

${ }^{11}$ Wyrok TS z 27 lutego 2014 r., w sprawie C-351/12, Ochranný svaz autorský pro práva k dílům hudebním o.s. przeciwko Léčebné lázně Mariánské Lázně a.s., niepubl.

${ }^{12}$ Pkt 36 wyroku w sprawie OSA. 
gdzie sygnał radiowy i telewizyjny doprowadzono do pokoi pacjentów. Na tle wyroku w sprawie $O S A$ widoczne jest wyraźnie, co zresztą nie budziło szczególnych wątpliwości, że państwa członkowskie muszą zapewnić przynajmniej taki poziom ochrony jak przewidziany w art. 3 ust. 1 dyrektywy 2001/29/WE, chyba że krajowe przepisy o dozwolonym użytku odpowiadaja postaciom dozwolonego użytku przewidzianym w art. 5 ust. 2 i 3 tejże dyrektywy.

Harmonizacja minimalna oznacza, że przepisy przyjęte w dyrektywie wyznaczają minimalny standard ochrony, jaki państwa członkowskie muszą zapewnić w prawie krajowym. W przypadku art. 3 ust. 1 dyrektywy 2001/29/WE $\mathrm{w}$ doktrynie europejskiej prezentowano stanowisko, że jest to prawie pełna harmonizacja ${ }^{13}$, ponieważ wyznaczone jest zarówno minimum obowiąujące państwa członkowskie, jak i maksimum, co oznacza, że państwa członkowskie nie moga przewidywać dalej idącej ochrony. Maksymalny charakter art. 3 ust. 1 czy też maksymalny charakter harmonizacji przewidzianej w dyrektywie 2001/29/WE nie jest wyraźnie wskazany w jej przepisach. W preambule dyrektywy wskazuje się na konieczność poprawienia pewności prawa oraz zapewnienia wysokiego poziomu ochrony, co jest celem harmonizacji ${ }^{14}$, a także że nie należy usuwać tych różnic w prawie krajowym, które nie powodują naruszeń $\mathrm{w}$ funkcjonowaniu rynku wewnętrznego ${ }^{15}$. W treści art. 3 ust. 1 dyrektywy 2001/29/WE o maksymalnym charakterze postanowienia można wnioskować ze wskazania na objęcie ,jakichkolwiek” sposobów publicznego udostępniania. Trudno wobec tak szerokiego zakresu przewidywać, że w państwach członkowskich można zapewnić ochronę „dalej idąca”. Ewentualne problemy rozstrzyga w tym zakresie wykładnia TS w sprawie Svensson ${ }^{16}$. Trybunał wskazał w tym wyroku, że art. 3 ust. 1 należy interpretować w ten sposób, że państwa członkowskie nie moga przyznać podmiotom prawa autorskiego szerszej ochrony, $\mathrm{w}$ drodze ustanowienia przepisu przewidującego, że pojęcie publicznego udostępniania obejmuje szerszy zakres działań niż wymienione w tym przepisie. Biorąc pod uwagę, że niewątpliwie w dyrektywie określono standard minimalny, a jednocześnie z wyroku w sprawie Svensson wynika maksymalny charakter harmonizacji w art. 3 ust. 1 dyrektywy 2001/29/WE, harmonizacja prawa do publicznego udostępniania utworów ma charakter pełny ${ }^{17}$. Można stwierdzić, że harmonizacja ta nie ma charakteru wyczerpującego, gdyż nie obejmuje wszystkich postaci publicznego udostępniania utworów, jakie mogą być objęte zakresem majątkowych praw autorskich w zakresie rozpowszechniania, wyłączając te formy, w których nie występuje tzw. element odległości, najczęściej

${ }_{13}$ A. Ohly, w: E. Derclaye (red.), Research Handbook on the Future of EU Copyright, Edward Elgar 2009, s. 225-226.

${ }^{14}$ Motyw 4 preambuły dyrektywy 2001/29/WE.

${ }_{15}$ Motyw 7 preambuły dyrektywy 2001/29/WE.

${ }^{16}$ Wyrok TS z 13 lutego 2014 r. w sprawie C-466/12, Nils Svensson, Sten Sjögren, M. Sahlman, P. Giad przeciwko Retriever Sverige AB.

${ }^{17}$ W doktrynie używa się pojęć „harmonizacja pełna”, „harmonizacja zupełna” i „harmonizacja wyczerpująca". Harmonizację minimalna przeciwstawia się harmonizacji pełnej czy zupełnej (ang. total harmonization), zob. P. Craig, G. de Búrca, EU Law Text, Cases and Materials, Oxford 2003, s. 1195. Czasem też przeciwstawia się harmonizację minimalną harmonizacji wyczerpującej, np. w kontekście dyrektyw przyjmowanych w zakresie ochrony konsumenta. I. Maletić, The Law and Policy of Harmonisation in Europe's Internal Market, Cheltenham 2013, s. 65-66. 
sprowadzający się do jakiejś formy transmisji. Poziom harmonizacji przewidziany w dyrektywie ma kluczowe znaczenie, jeśli chodzi o stosowanie przepisów polskiego prawa autorskiego zgodnie z prawem Unii.

\section{ODTWARZANIE NADAŃ W MIEJSCACH PUBLICZNYCH}

Podniesienie kwestii zarobkowego celu, jeśli chodzi o działalność uzdrowiska w sprawie OSA, wynika z tez TS zawartych we wcześniejszym wyroku w sprawie $S C F^{18}$. Rozważając, czy pojęcie publicznego udostępniania utworów obejmuje sytuację, w której dentysta w swoim gabinecie odtwarza muzykę, TS odpowiedział negatywnie. Trybunał wskazał, że jest to bezpłatne odtwarzanie fonogramów z korzyścią dla klientów, którzy korzystają z nadań nie ze swej woli. Odpowiedzi na pytanie prejudycjalne udzielono jednak na podstawie art. 8 ust. 2 dyrektywy w sprawie najmu i użyczania oraz niektórych praw pokrewnych $^{19}$, a więc $\mathrm{w}$ kontekście prawa do wynagrodzenia za określone postaci publicznego udostępnienia dla podmiotów praw pokrewnych. W sprawie OSA Trybunał podkreślił, że tezy z wyroku w sprawie $S C F$ nie mają znaczenia dla wykładni art. 3 ust. 1 dyrektywy 2001/29/WE, ponieważ dotyczy ona praw autorskich, a nie prawa o charakterze kompensacyjnym przysługującego podmiotom praw pokrewnych. Warto zauważyć, że TS nie miał okazji wypowiedzieć się w zakresie wykładni art. 3 ust. $1 \mathrm{w}$ kontekście sprawy bardzo zbliżonej do sytuacji korzystania z muzyki w gabinecie dentystycznym. Jednocześnie na liście wyjątków i ograniczeń przewidzianych w dyrektywie 2001/29/WE, w zakresie wyjątków od prawa do publicznego udostępniania utworów nie znalazło się postanowienie, które w sposób wyraźny dotyczyłoby takich form korzystania z utworów.

Mimo że co do zasady zastosowanie wykładni dyrektyw w konkretnym przypadku jest zadaniem sądu krajowego, w sprawie $S C F$ Trybunał uznał że ma do dyspozycji wszystkie okoliczności, aby ustalić, czy doszło do publicznego udostępnienia. W sprawie odtwarzania nadań (a pośrednio fonogramów) w gabinecie dentystycznym TS zwrócił uwagę na kilka kwestii. Po pierwsze, pacjenci dentysty stanowią krag osób w dużej mierze ustabilizowany i określony, w odróżnieniu od „ogółu ludności”"20. Liczba tych osób jest w zasadzie nieznacząca, a ponadto zmieniający się klienci nie są odbiorcami tych samych fonogramów ${ }^{21}$. Po drugie, odwołał się do odróżnienia osób, do których udostępniający celowo kieruje np. odtwarzanie fonogramów czy nadań, od takich, które sa uchwycone jedynie przypadkowo ${ }^{22}$ i nie sa, zdaniem TS, „podatne” na

18 Wyrok TS z 15 marca 2013 r. w sprawie C-135/10, SCF przeciwko Marco del Corso.

19 Dyrektywa 2006/115/WE Parlamentu Europejskiego i Rady z 12 grudnia 2006 r. w sprawie prawa najmu i użyczenia oraz niektórych praw pokrewnych prawu autorskiemu w zakresie własności intelektualnej, Dz. Urz. L 376 z 27 grudnia 2006 r., s. 28-35.

${ }^{20}$ Pkt 95 wyroku w sprawie $S C F$.

21 Pkt 97 wyroku w sprawie $S C F$.

22 Pkt 91 wyroku w sprawie $S C F$. 
odtwarzanie. Do takich należą klienci gabinetu dentystycznego, co wiąże się z faktem, że dentysta nie może rozsądnie oczekiwać zwiększenia liczby klientów lub podwyższać cen swoich usług w związku z takim odtwarzaniem, nie ma to zatem wpływu na dochody dentysty ${ }^{23}$. Biorąc pod uwagę, że teza TS, dotyczy zakresu pojęcia „publicznego udostępniania”, można mieć istotne wątpliwości, czy różnicowanie autorskich praw majątkowych i praw pokrewnych do wynagrodzenia za określone postaci udostępniania jest w tym wypadku uzasadnione. Co innego, gdyby teza TS, brzmiała, iż co prawda jest to publiczne udostępnianie, ale ze względu na brak korzyści majątkowych podmiotom praw pokrewnych nie należy się wynagrodzenie. To jednak mogłoby być jeszcze trudniejsze do uzasadnienia w świetle postanowień dyrektywy 2001/29/WE i dyrektywy 92/100 dotyczącej najmu i użyczania oraz niektórych praw pokrewnych.

Argumentacja TS w sprawie OSA może przemawiać za tym, że teza, iż określone udostępnianie nie ma publicznego charakteru ze względu na nieosiaganie korzyści majątkowych, nie znalazła potwierdzenia w wykładni art. 3 ust. 1. Aktualne jednak pozostaną rozważania, czy krag osób ma nieokreślony charakter i czy jest na tyle szeroki, że można mówić o „publiczności” w sensie ogółu ludności”. W prawie polskim oznaczałoby to konieczność rozważania, czy mamy do czynienia w ogóle $\mathrm{z}$ „udostępnieniem publicznym utworu”, a nie $\mathrm{z}$ zastosowaniem art. 24 ust. 2 pr.aut.

Warto zwrócić uwagę, że w odniesieniu do art. 24 ust. 2 pr.aut. Czajkowska-Dąbrowska mówi o nietypowej regulacji, wskutek której możemy mówić o „względnym” polu eksploatacji, podczas gdy zwykle wkroczenie w sferę podmiotowych praw autorskich następuje niezależnie od tego, czy sprawca odnosi jakąś korzyść majątkowa, czy nie ${ }^{24}$. Uwaga powyższa uwydatnia problem, który powstał na tle wyroku w sprawie $S C F$. W prawie polskim, ze względu na istniejące postanowienia dotyczące dozwolonego użytku, można przyjąć, że co prawda każde publiczne odtworzenie jest korzystaniem na polu eksploatacji w zakresie rozpowszechniania utworu, ale pod pewnymi warunkami nie wymaga się zgody podmiotów uprawnionych ani nie jest konieczne zapłacenie wynagrodzenia. Sedno problemu jest jednak takie samo, mianowicie, w jakim zakresie wolno korzystać z nadawanych programów, co zgodnie z odesłaniem w art. 100 pr.aut. będzie odnosiło się również do podmiotów praw pokrewnych, czyli np. do producentów fonogramów, których roszczenia były przedmiotem sporu w sprawie $S C F$.

W orzecznictwie sądów polskich przewijają się dwa wątki rozważań dotyczace stosowania art. 24 ust. 2 pr.aut. Jeden dotyczy przesłanek uznania, że korzystanie nie łączy się z osiąganiem korzyści majątkowych, a drugi rozkładu ciężaru dowodu. W obu kwestiach wypowiedział się Sąd Najwyższy. Najpierw, w 2004 r., wskazał, że zgodnie z ogólną regułą rozkładu ciężaru dowodu konieczność udowodnienia, że nie osiagnięto korzyści majątkowych, leży po stronie podmiotu, który z tego faktu chce wywodzić brak konieczności

\footnotetext{
${ }^{23}$ Pkt 97 wyroku w sprawie $S C F$.

${ }^{24}$ M. Czajkowska-Dąbrowska, op. cit., s. 586.
} 
uzyskania zgody użytkownika ${ }^{25}$. W 2005 r. w uzasadnieniu wyroku dotyczącego odtwarzania muzyki w sieci sklepów z obuwiem luksusowym znajdujemy wskazówki, jak bliżej rozumieć brak osiagania korzyści majątkowych ${ }^{26}$. Obie kwestie łacznie maja kluczowe znaczenie dla stosowania art. 24 ust. 2 w praktyce, sprowadzaja się bowiem do tego, co ma udowodnić strona, do której roszczenia kierują organizacje zbiorowego zarządzania. Stanowisko, że nieuzyskanie korzyści majątkowych jest „faktem prawo niweczącym”, poddała krytyce Czajkowska-Dąbrowska, wskazując na inne możliwości podejścia do oceny dowodów z uwagi na trudności z udowodnieniem tzw. okoliczności negatywnych ${ }^{27}$. W wyroku z 2005 r. Sąd Najwyższy potwierdził swoje stanowisko, że przyjęcie innego rozkładu obowiązku dowodowego, niż wynika z ogólnej reguły dowodowej $\mathrm{z}$ art. 6 k.c., jest niedopuszczalne ze względu na to, że wykładni podlega wyjątek od prawa wyłącznego. Sądom, które rozpatrywać będa powstałe na gruncie art. 24 ust. 2 pr.aut. spory, służyć powinna wykładnia $\mathrm{SN}$, że sytuacje, w których odtwarzanie utworów w ramach prowadzonej działalności gospodarczej nie będzie się łączyć z osiaganiem korzyści majątkowych dla odtwarzającego, powstaną przede wszystkim wtedy, gdy klienci nie będa poddawani oddziaływaniu odbioru. Przede wszystkim, zdaniem Sądu, może to mieć miejsce na małych powierzchniach handlowych, w drobnych zakładach usługowych, w których odtwarzanie służy zapełnieniu czasu personelowi. Jeśli natomiast są to większe przestrzenie handlowe, w których klient przebywa dłuższą chwilę, odtwarzanie powinno być zakwalifikowane jako połączone z korzyściami majątkowymi ${ }^{28}$.

W powyższym, często cytowanym w orzecznictwie sądów apelacyjnych fragmencie uzasadnienia zwraca uwagę odwołanie się do kryteriów podobnych do tych, na które wskazano w sprawie $S C F$. Po pierwsze - mowa o „poddawaniu oddziaływaniu odbioru”, po drugie - odwołano się do wielkości powierzchni. Sama wielkość sklepu czy innego lokalu wydaje się mieć znaczenie drugorzędne. W analizie Trybunału Sprawiedliwości Unii Europejskiej argument ten może służyć jako poparcie tezy, że w ogóle nie dochodzi do udostępnienia publicznie, natomiast w prawie polskim przyjęto, że nawet jeśli mamy do czynienia z udostępnieniem public znie, jest to dozwolone, jeśli nie łączy się z tym osiaganie korzyści majątkowych. Językowa analiza art. 24 ust. 2 pr.aut. może rzeczywiście prowadzić do wniosku, że to posiadacze urządzeń, a nie osoby postronne, mogą odbierać, a zatem korzystać z nadawanych utworów. Stąd wniosek, że klienci nie powinni być poddawani „oddziaływaniu odbioru”, co wydaje się wprowadzać różnicę między kierowaniem programów radiowych lub telewizyjnych do klientów posiadacza odbiornika a niezamierzoną możliwościa, że klienci usłyszą lub zobaczą nadawane programy. Biorąc pod uwagę, że w szczególności nie wszystkie programy telewizyjne sa kierowane do nieograniczonego odbioru, np. telewizje kodowane, na co wskazuje przykład

${ }^{25}$ Wyrok SN z 18 listopada 2004 r., V CK 243/04, OSP 2005, nr 11, poz. 129.

26 Wyrok SN z 18 września 2005 r., I CK 164/05, Lex, nr 356104.

${ }_{27}$ M. Czajkowska-Dąbrowska, op. cit., s. 587 (z powołaniem na poglądy J. Ignatowicza).

28 Wyrok SN z 18 września 2005 r. 
rozpatrywanej przed TS sprawy Premier League ${ }^{29}$, chęć przyciagania klientów przez odtwarzanie nadań nie jest bez znaczenia. Nadal jednak można twierdzić, że najistotniejszym elementem uznania, czy dochodzi do uzyskiwania korzyści majątkowych, jest to, czy odtwarzanie łączy się ze wzrostem zainteresowania klientów, zwiększeniem obrotów, czy z możliwością podnoszenia cen. Trybunał wyraźnie bierze to pod uwagę, natomiast wątku tego nie rozwiną Sąd Najwyższy w wyroku z 2005 r.

Uwagi odnoszące się do związku pomiędzy odtwarzaniem programów a osiaganiem korzyści majątkowych w ramach prowadzonej działalności gospodarczej można natomiast odnaleźć w orzecznictwie sąów apelacyjnych. W wyroku z 2008 r. Sąd Apelacyjny w Katowicach podkreślił, że możliwość wykazania nieosiagania korzyści majątkowych nie może być jedynie pustym zapisem i moga istnieć takie sytuacje, w których nie zachodzi nawet pośredni wpływ odbioru nadawanych utworów na powodzenie prowadzonej działalności ${ }^{30}$. W uzasadnieniu Sąd Apelacyjny wskazał, że radio w lokalu pozwanego (restauracji serwującej głównie niedrogie zestawy obiadowe) nie było elementem funkcjonalnie związanym z prowadzeniem działalności usługowej. Apelacja organizacji zbiorowego zarządzania została w tym wypadku oddalona, jednakże część rozważań poświęcona jest nie tyle kwestii, czy zachodzi przesłanka „nieuzyskania korzyści majątkowych”, ile czy w ogóle mamy do czynienia z udostępnieniem publicznie, co nie wymagałoby wykładni art. 24 ust. 2

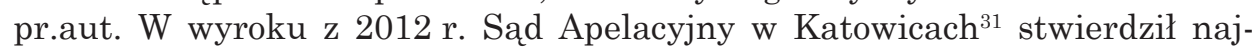
pierw, że sformułowanie „nie łączy się z tym” osiaganie korzyści majątkowych przemawia za przyjęciem, iż chodzi nie tylko o działalność zarobkową opartą na korzystaniu z programów radiowych i telewizyjnych, lecz także gdy nie stanowi ono głównego elementu takiej działalności. W przypadku przydrożnego zajazdu, jak ocenił Sąd Apelacyjny, wybór podróżnych może zależeć od ogólnego klimatu lokalu, na co ma wpływ telewizor umieszczony w ten sposób, by oglądali go również klienci. Co do zasady można rozumieć, że w omawianym przypadku nie zachodzą okoliczności, w których zastosowanie znajdzie art. 24 ust. 2. Przyczyna zmiany zaskarżonego wyroku na korzyść pozwanego prowadzacego zajazd była w tym przypadku analiza, jakie programy były odtwarzane w lokalu (informacyjne), i roszczenia związane z nadawaniem utworów muzycznych. Dodatkowym aspektem, na jaki zwrócił uwagę Sąd Apelacyjny, jest rodzaj programów: o ile nadawanie ciekawych programów telewizyjnych może wpływać na klientelę (nie określono bliżej, w jaki sposób), o tyle nadawanie reklam nie stanowi elementu uatrakcyjniajacego lokal. Z kolei Sąd Apelacyjny w Krakowie w 2013 r. stwierdził, że wystarcza, by publiczne odtwarzanie mogło się „przyczyniać do powiększania rozmiaru przychodów w ramach zamierzenia gospodarczego o profilu dobrowolnie wybranym [...]”. W konkretnym rozpatrywanym przypadku odtwarzania programów radiowych w pizzerii,

${ }^{29}$ Wyrok TS z 4 października 2011 r. w sprawach połączonych C-403/08, Football Association Premier League Ltd. $i$ inni przeciwko Q. C. Leisure i inni, i C-429/08, Karen Murphy przeciwko Media Protection Services, Zb. Orz. 2011, I-09083.

30 Wyrok SA w Katowicach z 14 marca 2008 r., IACa 102/08, Lex, nr 447157.

31 Wyrok SA w Katowicach z 13 kwietnia 2012 r., I ACa 129/12, Lex, nr 1213876. 
przedsiębiorca nawet nie próbował wykazać, że nie odnosi korzyści majątkowych $^{32}$. Szeroko dyskutowanym nie tylko w mediach ${ }^{33}$ przypadkiem jest spór sądowy pomiędzy fryzjerem a organizacją zbiorowego zarządzania. W sprawie tej granic absurdu sięgnęła zresztą kwestia udowodnienia okoliczności negatywnych, na trudności z czym wskazywały również wspomniane sądy apelacyjne. Fryzjer rozdawał bowiem swoim klientom zatyczki do uszu i prosił o podpisanie oświadczenia, że nie słuchają u niego muzyki ${ }^{34}$.

$\mathrm{Na}$ tle rozpatrywanych spraw można stwierdzić, że czynnikiem, który należy brać pod uwagę, jest związek pomiędzy odtwarzaniem nadań programów a korzystaniem z danej usługi (w praktyce orzecznictwo dotyczy właśnie różnego rodzaju usług, np. restauracyjnych, fryzjerskich czy też handlowych). Przy takim ujęciu, niezależnie od wielkości powierzchni, jak również niezależnie od tego, czy klienci faktycznie słyszą muzykę, uwaga powinna być skupiona na tym, co z tego faktu, iż słyszą lub oglądaja, wynika. W tym miejscu można się posłużyć wskazówkami, których udzielił TS, mając jednak na uwadze, że dotyczą one określenia zakresu prawa do publicznego udostępniania, a nie zastosowania regulacji wprowadzającej wyraźny wyjątek, tak jak w prawie polskim. W konsekwencji uwagi krytyczne zgłaszane pod adresem wyroku TS w zakresie, w jakim brak przesłanki zarobkowego celu może wykluczać uznanie za „publiczne udostępnienie”, oraz zróżnicowania pomiędzy zakresem praw autorskich i pokrewnych nie moga być odnoszone do wykładni prawa polskiego. Głośna sprawa fryzjera z Wałbrzycha pokazuje, że łatwo skupić uwagę na tym, czy faktycznie doszło do udostępnienia publicznie, a nie na związu takiego udostępnienia z osiaganiem korzyści majątkowych.

Odmienną kwestią jest, czy istniejąca w prawie polskim regulacja, mimo że może służyć wyważeniu interesów korzystających i uprawnionych i jest zgodna z duchem wyroku w sprawie $S C F$, jest również zgodna z wymogami prawa UE. Przypomnieć należy, że w odniesieniu do praw autorskich ustawodawca może wprowadzać tylko takie wyjątki, które są przewidziane na liście ograniczeń i wyjątków harmonizowanych dyrektywą 2001/29/WE. Wydaje się, że jedynym przepisem, który mógłby uzasadniać istnienie wyjątku w prawie polskim, jest art. 5 ust. 3 lit. o - można więc w prawie krajowym utrzymać takie wyjątki i ograniczenia, które istniały w nim już wcześniej, sa przypadkami o mniejszym znaczeniu, dotycza jedynie analogowych form korzystania i nie naruszają swobodnego przepływu towarów i usług na rynku wewnętrznym. Pierwszy wymóg jest oczywiście spełniony. Problematyczna może być kwestia „analogowego korzystania”, z jednej strony nadania stają się prawie wyłacznie cyfrowe, z drugiej - można bronić stanowiska, że korzystanie z urządzeń, na-

${ }^{32}$ Wyrok SA w Krakowie z 5 czerwca 2013 r., I ACa 473/13, http://orzeczenia.ms.gov.pl/ details/art.24\$0020ust.2\$0020prawo\$0020autorskie/152000000000503_I_ACa_000473_2013_ Uz_2013-06-05_001 (dostęp: 9.06.2015).

${ }_{33}$ Przykładowo dyskusje na blogach prawniczych: http://blogprawny.mrip.com.pl/kazus-fryzjer-ca-zaiks-rozwazania-prawne/; czy w podczas konferencji CopyCamp: http://copycamp.pl/info/ program-wystapien/ (dostęp: 9.06.2015).

${ }^{34}$ Zob. http://wyborcza.pl/1,75478,16551733,Fryzjer_znow_wygrywa_z_ZAiKS_em_Sad_oddala_apelacje.html (dostęp: 9.06.2015). 
wet cyfrowych, polegające na odtwarzaniu jest jednak korzystaniem w sposób „,analogowy”. Brzmi to bardzo niezręcznie i wydaje się, że nazwanie takiego korzystania „analogowym” jest nieadekwatne, ale mimo to istotne jest, iż nie jest to korzystanie w obrocie elektronicznym ani w Internecie. Mimo wszystko większe problemy powstaną z udowodnieniem, że jest to przypadek o mniejszym znaczeniu i nie wpływa na swobodny przepływ usług w szczególności. Biorac pod uwage liczne wyroki TS dotyczące właśnie odtwarzania w takich miejscach, jak hotele, puby czy gabinet dentystyczny, można twierdzić, że sam fakt, iż Trybunał odpowiada na takie pytania prejudycjalne, świadczy o tym, że nie jest to kwestia bez znaczenia z punktu widzenia harmonizacji praw autorskich i pokrewnych. Harmonizacja ta uzasadniana jest związkiem z rozwojem rynku wewnętrznego, w szczególności z wykorzystaniem możliwości, jakie przyniósł Internet. Jednakże można też argumentować, że przypadki korzystania, które nie łączą się z osiąganiem korzyści majątkowych, nie wpływają zasadniczo na korzystanie ze swobód gospodarczych. Jeśli jednak stanowisko takie nie zostałoby przyjęte, należałoby uznać, że art. 24 ust. 2 pr.aut. jest niezgodny z prawem Unii. Byłoby to swego rodzaju paradoksem, gdyż w prawie polskim istnieje wyraźna podstawa do prowadzenia rozważań analogicznych do prowadzonych przez TS w sprawie $S C F$, w której może to budzić wątpliwości. Istnieją zatem podstawy do osiagnięcia rezultatu wskazanego przez TS, ale podstawy te mogą być w formalnej sprzeczności z dyrektywą 2001/29/WE.

\section{PROBLEM UDOSTEPPIANIA LINKÓW JAKO ROZPOWSZECHNIANIA UTWORÓW}

Trybunał Sprawiedliwości Unii Europejskiej budował swoją linię orzeczniczą dotycząca stosowania art. 3 ust. 1 dyrektywy 2001/29/WE w kontekście sporów o reemisję albo publiczne odtwarzanie, a nie w kontekście sporów o korzystanie z nowych technologii ${ }^{35}$. W sprawie Svensson skierowano pytanie prejudycjalne dotyczące kwalifikacji zamieszczania odesłań internetowych jako publicznego udostępniania utworów, co ma bardzo istotne znaczenie dla funkcjonowania Internetu. W odpowiedzi TS wskazał, że udostępnienie na stronie internetowej linków, które odsyłają do utworów ogólnie dostępnych na innej stronie, nie stanowi czynności publicznego udostępnienia, jeśli utwory te są ogólnie dostępne. Odwracając tę tezę, można stwierdzić, że zdaniem TS, zamieszczenie linków do utworów, które nie są ogólnie dostępne, stanowi ich publiczne udostępnienie, w rozumieniu art. 3 ust. 1 dyrektywy 2001/29/WE. Z uzasadnienia wyroku wynika, że zezwolenie podmiotów uprawnionych nie

${ }^{35} \mathrm{~W}$ zakresie nowych technologicznie sposobów eksploatacji pierwszy interesujący wyrok w sprawie ITV Broadcasting dotyczył internetowej retransmisji programów telewizyjnych. Wyrok TS z 7 marca 2013 r. w sprawie C-607/11, ITV Broadcasting Ltd i inni przeciwko TV CatchUp Ltd., niepubl. 
jest konieczne dlatego, że nie mamy do czynienia z udostępnieniem dla „nowej publiczności" ${ }^{36}$.

Tezy wyroku w sprawie Svensson z jednej strony przypieczętowują istniejącą linię orzecznicza, w związku z tym, że TS wskazał na maksymalny charakter harmonizacji. Z drugiej - wyrok pozostawia szereg wątpliwości co do stosowania przyjętego przez TS kryterium: nowej publiczności. Można przy tym wnosić, że stwierdzenie o maksymalnym charakterze harmonizacji ma znaczenie szczególnie w kontekście udostępniania linków (odesłań internetowych) i ma na celu zapobieganie rozbieżnym rozstrzygnięciom sądów krajowych oraz wprowadzaniu w prawie krajowym ewentualnych rozwiązań dotyczacych zamieszczania linków niezgodnych z wykładnią TS. Niebezpieczeństwo takie realnie istnieje, ponieważ kwestia jest bardzo kontrowersyjna i istnieją różne propozycje wykładni w tym zakresie ${ }^{37}$. Wydane przez Trybunał postanowienie w sprawie BestWater ${ }^{38}$, w którym wskazano, że kwestia zamieszczania linków internetowych jest już wystarczajacco wyjaśniona w orzecznictwie, może być argumentem na to, że gdy chodzi o wykładnię przepisów stanowiących implementację art. 3 ust. 1 dyrektywy 2001/29/WE, zastosowanie znaleźć powinna doktryna acte éclairée.

W maju 2014 r. do problemu zamieszczania linków w świetle polskiego prawa autorskiego miał okazję ustosunkować się Sąd Apelacyjny w Warszawie $^{39}$. Spór dotyczył zamieszczenia odesłania na publicznym profilu kandydata w wyborach do Sejmu. Link umożliwiał bezpośrednie zapoznanie się z plikiem muzycznym zmontowanym przez nieznanego autora, który stanowił przeróbkę utworu muzycznego jednego z poznańskich artystów. Powodem w sprawie był właśnie ów artysta, który twierdził, że zamieszczenie odesłania do materiału muzycznego, który stanowił przeróbkę naruszająca jego prawa autorskie, jest również naruszeniem jego praw autorskich. Na tle tego sporu, w którym poruszono również wątki związane z przeprowadzaniem kampanii wyborczej, Sąd Apelacyjny w Warszawie ustosunkował się m.in do kwestii fundamentalnej dla funkcjonowania Internetu, jaka jest zamieszczanie linków. Jednym z zarzutów podniesionych $\mathrm{w}$ apelacji pozwanego był zarzut naruszenia art. 6 ust. 1 pkt 3 pr.aut. przez błędną wykładnię i przyjęcie błędnego poglądu, że umieszczenie linku, w tym tzw. głębokiego linku do dostępnego w sieci Internet utworu, jest jego publicznym udostępnieniem, a więc rozpowszechnieniem. Sąd Apelacyjny wziął pod uwagę wyrok TS w sprawie Svensson i wyraźnie się na niego w swym uzasadnieniu powołał. Problem linków rozpatrzono, podobnie zresztą jak w wyroku TS, w świetle uprawnienia do publicznego

${ }^{36}$ Pkt 28 wyroku w sprawie Svensson.

${ }^{37}$ Zob. np. T. Pihlajarinne, Setting the Limits for the Implied License in Copyright and Linking Discourse - the European Perspective, „IIC - International Review of Intellectual Property and Competition Law" 43, 2012, nr 6, s. 700-710; K. Moruń, Odpowiedzialność prawna za odestania $w$ Internecie, „Przegląd Prawa Handlowego” 2010, nr 12, s. 40; W. Szpringer, Linking i framing - czy nowe wyzwanie dla prawa Internetu?, „Przegląd Ustawodawstwa Gospodarczego” 2005, nr 4 , s. 28.

${ }^{38}$ Postanowienie TS z 21 października 2014 r., w sprawie C-348/13, Bestwater International GmbH przeciwko M. Mebes i S. Potsch, niepubl.

${ }^{39}$ Wyrok SA w Warszawie z 7 maja 2014 r., I ACa 1663/13, http://orzeczenia.ms.gov.pl/ details/\$N/154500000000503_I_ACa_001663_2013_Uz_2014-05-07_001 (dostęp: 9.06.2015). 
udostępniania utworów w taki sposób, aby każdy mógł mieć do niego dostęp w miejscu i czasie przez siebie wybranym. Polski sąd wyraźnie zgodził się z wyjściową tezą TS, że: „wstawienie odnośnika - linku, którego kliknięcie powoduje przeniesienie do lokalizacji internetowej, w której utwór się znajduje i odtworzenie utworu" stanowi udostępnienie utworu. Ta zgoda tylko pozornie jest pełna, o czym świadczą ostatnie słowa cytowanego fragmentu: „i odtworzenie utworu". Sąd Apelacyjny dalej wskazuje bowiem, że wniosek TS w sytuacji, w której następuje samo przeniesienie do strony z utworem, wydaje się daleko idący i zdaniem Sądu czynność zamieszczenia linku sama w sobie nie dotyczy utworu. Ani udostępniajacy, ani korzystajacy z linku nie korzystają z samego utworu. Sąd Apelacyjny zwrócił uwagę na efekt użycia linków i - jak można rozumieć - wyodrębnił korzystanie z linków typu embedded links, których cechą charakterystyczną jest to, że utwór jest odtwarzany na stronie osoby, które zamieściła link, tak jak w okolicznościach sprawy będacej przedmiotem sporu, kiedy utwór odtwarzano po naciśnięciu ikony „play”. Takiego rozróżnienia nie przeprowadził Trybunał, co dodatkowo potwierdza odniesienie do tzw. inline links ${ }^{40} \mathrm{w}$ postanowieniu w sprawie BestWater. Niezależnie od tego, czy jest to proste i wyraźne odesłanie do utworów zamieszczonych na innej stronie, czy ich „wbudowanie” w stronę zamieszczającego link, TS nakazuje skoncentrować się na spełnieniu przesłanki „nowej publiczności”. Polski sąd jednak zakwestionował stosowanie przesłanki „nowej publiczności”, krytycznie odnosząc się do wywodów TS. Zdaniem Sądu Apelacyjnego przesłanka ta nie jest warunkiem sine qua non uznania za publiczne udostępnienie. Podsumowując dokonaną wykładnię, Sąd Apelacyjny przychylił się do tezy, że aby doszło do udostępnienia, o którym mowa w art. 50 pkt 3 (udostępnianie na żądanie), wystarczy zamieszczenie linku, który po woduje odtwarzanie utworu. Kluczowe w sprawie jednak było to, że Sad Apelacyjny uznał, iż podmiotem praw autorskich do wykorzystanego utworu nie był powód w sprawie, a ten, kto sporządził przeróbkę. W tej konkretnej sytuacji zamieszczenie linku nie prowadziło do konsekwencji z tytułu odpowiedzialności za naruszenie praw autorskich.

W postanowieniu w sprawie BestWater (wydanym później niż wyrok Sądu Apelacyjnego w Warszawie) Trybunał wskazał, że odpowiedź na pytanie dotyczące zamieszczanie linku, który powodował odtworzenie filmu na stronie konkurentów spółki BestWater i sprawiał wrażenie, że to sam utwór, a nie link został przez nich zamieszczony, jest jasna w świetle dotychczasowego orzecznictwa $\mathrm{TS}^{41}$. Wydaje się w związku z tym, że podtrzymywanie wykładni takiej, jaką zaproponował Sąd Apelacyjny w omawianym wyroku, może prowadzić do naruszenia orzeczniczej zasady acte éclairée i prowadzić do wydawania wyroków sprzecznych z wykładnią TS. Rozwój wykładni w stronę rozróżnienia różnych typów linków w zależności od efektu, jaki wywołuja, nie jest pozbawiony racji, ale ta droga została jednak tymczasowo zamknięta przez TS.

${ }^{40}$ Pojęcie inline linking wyjaśnia się jako wykorzystywanie materiału, do którego zamieszczony jest link, często obrazu, na innej stronie internetowej; http://en.wikipedia.org/wiki/Inline_linking (dostęp 9.06.2015). Prowadzi to do korzystania w taki sposób, jak gdyby powstawała kopia obrazu, jednakże techniczne rzecz biorac, jest to tylko zamieszczenie linku.

${ }^{41}$ Pkt 12 postanowienia w sprawie BestWater. 


\section{PODSUMOWANIE}

Główne, sprzężone ze sobą czynniki będące przyczyną wprowadzonych w ustawie pr.aut. zmian to postęp technologiczny i rozwój nowych sposobów eksploatacji utworów oraz konieczność dostosowania prawa polskiego do wymogów prawa Unii Europejskiej. Wskutek dostosowania treści polskiej ustawy do dyrektyw unijnych w momencie akcesji Polski można było mówić o zasadniczym zapewnieniu twórcom takiego zakresu uprawnień do rozporządzania i korzystania w sferze rozpowszechniania utworów, jaki jest wymagany zgodnie $\mathrm{z}$ unijnym standardem. Przeprowadzona analiza prowadzi jednak do wniosku, że zapewnienie pełnej zgodności prawa polskiego i prawa Unii Europejskiej w zakresie prawa do rozpowszechniania utworów może z kilku powodów być problematyczne.

W zakresie omówionych przepisów wątpliwości można mieć co do obowiązywania art. 24 ust. 2 pr.aut. Warto zauważyć, że TS dokonuje wykładni pojęć zawartych w dyrektywie, co w praktyce prowadzi do określenia rezultatu, do którego osiagnięcia zobowiązane są państwa członkowskie. Jednocześnie wykładnia TS nie jest wykładnią przepisów stanowiących element zupełnego i spójnego prawodawstwa w zakresie prawa autorskiego, mimo szerokiego zakresu harmonizowanych zagadnień. Wyraźnie widać to w orzeczeniach, w których TS bierze pod uwagę przesłankę „zarobkowego celu” korzystania, co prowadzi nawet do wniosków o zakresie prawa do publicznego udostępniania utworów, w rezultacie wprowadzając de facto odstępstwo od prawa wyłaccznego. Z kolei istnienie takiego odstępstwa w prawie krajowym, nawet ściśle interpretowanego, może być formalnie niezgodne $\mathrm{z}$ prawem UE.

Natomiast w przypadku problemu zamieszczania odesłań internetowych, jeśli chodzi o rozwiązania ustawowe, istnieje zgodność ze zobowiązaniami wynikającymi z dyrektywy 2001/29/WE. Jednakże, mimo formalnej zgodności, w świetle wyroku Sądu Apelacyjnego w sprawie zamieszczenia odesłania internetowego zaproponowano wykładnię odmienna, sprzeczną z wykładnia Trybunału Sprawiedliwości. Sąd Apelacyjny w Warszawie słusznie zauważył słabości argumentacji TS i zaproponował wykładnię godną dalszej uwagi. Wobec wielu wątpliwości, jakie budzi wykładnia TS w sprawie zamieszczania odesłań, trudno uważać tę kwestię za niepodlegającą dalszej dyskusji w doktrynie i de lege ferenda. Natomiast de lege lata istnieje niebezpieczeństwo, że sądy polskie będą rozstrzygać wbrew wykładni TS ${ }^{42}$.

dr Katarzyna Klafkowska-Waśniowska

Uniwersytet im. Adama Mickiewicza w Poznaniu

kwasn@amu.edu.pl

${ }^{42} \mathrm{Na}$ temat innych orzeczeń sądów apelacyjnych na temat zamieszczania odesłań internetowych i naruszania dóbr osobistych np. A. Wójcik, Glosa do wyroku Sadu Apelacyjnego w Katowicach z dnia 18 grudnia 2013 r. w sprawie ACa 524/13, „Forum Prawnicze” 2014, nr 3(23), s. 46-51, http://admin.forumprawnicze.eu/dir_upload/site/files/FP23/Wojcik.pdf (dostęp: 9.06.2015). 


\title{
PUBLIC COMMUNICATION OF WORKS AND THE HARMONISATION OF AUTHOR'S ECONOMIC RIGHTS IN THE EUROPEAN UNION LAW
}

\author{
Sum mary
}

The aim of the article is to present and analyse the key questions concerning the scope of the right to communicate the works to the public under Polish law. The provisions of the Polish Act on Copyright and Related Rights concerning the public communication right has changed in the last two decades due to the implementation of the European Union law. Furthermore, it follows from the recent ruling of the Court of Justice of the European Union (CJEU) that the public communication right is fully harmonised in Article 3.1 of the Information Society Directive. Therefore, the interpretation of the scope of the public communication right in the CJEU's judgments is crucial for the correct application of the provisions of Polish law. The article commences with presentation of the development of the provisions of Polish Act on Copyright and Related Rights, then the most important rulings of the CJEU are discussed with the emphasis on the meaning of 'the public' and the level of harmonisation. Against this background the specific Polish provisions on the communication of broadcasts to the public are presented and the compliance with the EU law is questioned. In the last part the approach to the placing hyperlinks as an act constituting the public communications of works is compared in the CJEU's ruling and the approach by Polish court. 
